\title{
Considerations in Pension Reforms: A Review of the Challenges to Sustainability and Distributive Impartiality
}

\author{
Evangelos Koutronas ${ }^{a}$ \\ Siew-Yong Yew ${ }^{b}$ \\ University of Malaya
}

\begin{abstract}
This paper examines the impact of welfare reforms on the sustainability of public pension schemes. The paper reviewed past and current literature and practices of various countries to evaluate the effectiveness of reforms used from the aspect of structural and systemic parameters focusing on sustainability and distributive impartiality. This review concludes that there are no ideal pension scheme but there are reforms that have shown to be beneficial to the sustainability and distributive impartiality of pension systems and such reforms should be applied in combination to suit the economic dynamism of each individual country.
\end{abstract}

Keywords: Pension reforms, public pensions

JEL classification: E17, E21, H55

\section{Introduction}

The debate on pension reforms has become a prominent theme of public policy since the 1970s and implementation of pension reforms have been as frequent as diverse (Ahsan et al., 1986; Holzmann, 1988; World Bank, 1994). Slowing and less stable economic development, higher inflation and unemployment rates gradually undermined the financial strength of public pension schemes and created an environment that was much less favourable to their expansion than in the preceding two decades. The initial pension fund surpluses gradually became the implicit pension debt that was building up (Kane \& Palacios, 1996; Van Der Nood \& Herd, 1994).

The initial public pension schemes reached maturity when the first generation of retirees begun to retire. Pension outlays outweighed tax revenues turning thus surplus into deficit and the implications of benefit expenditures become observable on public finances. Governments initially proceeded to systemic reforms, reshaping the functions of public pension schemes. However, the challenge remained on how to prolong the financial life of the existing pension systems while maintaining their efficiency. Past and current literature had argued that many public pension systems are financially unsustainable in their present form (Davis, 1995; Fox \& Palmer, 2001; Lakonishok, Shleifer, \& Vishny, 1992; Vittas, 1993). However, if governments delay reforms, then the scale of adjustment needed in the short or the long run will be more drastic and afflictive.

a Faculty of Economics and Administration, University of Malaya, 50603 Kuala Lumpur, Malaysia. Email: evangel_gr@um.edu.my, evangel_gr@yahoo.com

b Faculty of Economics and Administration, University of Malaya, 50603 Kuala Lumpur, Malaysia. Email: yewsy@um.edu.my (Corresponding author)

* This research did not receive any specific grant from funding agencies in the public, commercial, or nonprofit sectors. 
This study aims to review the current pension systems practised by countries globally, existing proposed reforms to pension systems from literature, and address issues theoretically on our proposed reforms to current pension systems. It will focus, in particular, on the policy choices within the pension system itself. The study seeks to identify major reform policies, pinpoint their deficiencies, map their patterns and discuss key lessons learned. The literature review, although not fully exhaustive, will present important findings that may distil insightful connotations to alternative paths for reform.

The remainder of this paper is structured as follows. Section two outlines the challenges pension systems are facing and summarises the main features of reform policies. The following sections describe the advantages and disadvantages of the actual and potential reform policies. Section six considers an optimal pension design. The final section concludes.

\section{Pension Reforms from the Past}

A substantial literature has identified several factors responsible for the erosion of pension systems (Davis, 1995; Fox \& Palmer, 2001; Lakonishok et al., 1992; Vittas, 1993). Firstly, the demographic trends suggest rapid ageing due to declining fertility rates and increasing longevity. Both of these have a negative impact on economic growth, household behaviour, labour markets, pension benefits, state revenues and redistribution of income. Socially, they affect family cohesion and functioning, living arrangements, housing and migration. Health care expenditures had also been growing at a faster rate than average income resulting in higher contribution rates or the curtailment of benefits (Weber, 2010).

Secondly, pension reforms face daunting barriers. In developed countries, existing legal and regulatory framework related to social welfare and institutional rigidity constrain reform policies (Pierson, 1999). In developing countries, socioeconomic imbalances accompanied by poor infrastructure quality and underdeveloped capital markets leave only a few of them able or willing to implement social security reforms. Political pressures also impose roadblocks to the formulation of welfare policies with redistributive features (Newbery \& Stern, 1987; Radian, 1980).

Pension reforms which began in the 1980s and 1990s were triggered by exogenous (radical technological changes, market liberalisation, demographic changes and the loss of control on the side of states in the financial, monetary and incomes policy) as well as endogenous factors (welfare structure inefficiency). Several countries proceeded to moderate improvements of their existing pension systems (Muller, 2001; Pierson, 1999). Others found fully-funded schemes more attractive for their capital accumulation higher rates of return. However, many countries expedited system transitions, from traditional defined-benefit pay-as-you-go systems to defined-contribution fully funded systems (OECD, 2000).

The spectrum of reform arrangements was mainly parametric and systemic in nature. The former involves automatic adjustment mechanisms that could help address actuarial balance challenges, without affecting the structural characteristics of public pension schemes. Parametric initiatives aimed at optimising system efficiency, thereby focusing on ad hoc changes, such as the retirement age, replacement rate, contribution 
rate and benefit indexation (Brooks, 2009; Hur, 2010; Modigliani \& Muralidhar, 2004; Schwarz \& Demirguc-Kunt, 1999).

All countries, except Greece, linked pension age to rising life expectancy. Some countries (e.g. Lithuania, Greece, Bermuda, Latvia and Paraguay) also changed the years of service required prior to pension entitlement (Schwarz \& Demirguc-Kunt, 1999). Several European countries (e.g. Finland, Sweden, Germany, France, Italy, Portugal and Switzerland) concentrated on reducing replacement rates, and even lowering pension distributions (Modigliani \& Muralidhar, 2004). South American countries (e.g. Brazil, Peru and Chile) did exactly the opposite (Brooks, 2009). Asian countries (e.g. Japan, Korea, Taiwan, Hong Kong and Singapore) adopted a mixture of both sides (Hur, 2010).

The latter usually encompasses the composition of a new defined-contribution component, a fully funded pillar inside, or outside of the existing apparatus (Ponds, Severinson, \& Yermo, 2011; Schwarz \& Demirguc-Kunt, 1999). In some countries public sector employees were transferred to the main public pension system (e.g. Austria, Chile, Czech Republic, Greece, Hungary, Mexico, Poland, Spain and the United States), which in some cases included a fully-funded, defined-contribution component (e.g. Chile, Denmark, Hungary, Mexico and Poland) (Ponds et al., 2011). In several countries (e.g. Chile, Mexico, El Salvador, Bolivia, Poland, Hungary and Kazakhstan), reform arrangements entailed transition mechanisms to support a new fully-funded system. Few countries though, either switched from pay-as-you-go to individual notional accounts (Latvia, Sweden, Italy and Poland), or from provident funds to pay-as-you-go system (Nigeria) (Schwarz \& Demirguc-Kunt, 1999).

Literatures on empirical research concluded that the majority of policy initiatives prompted adverse implications of addressing sustainability issues in public pension schemes. Reform arrangements generally focused on curbing pension expenditures rather than advancing funding and/or financing mechanisms (Disney, 2000; Hauner, Leigh, \& Skaarup, 2007; Schneider, 2009; World Bank, 1994). Public pension schemes can "provide adequate, affordable, sustainable and robust benefits" (Holzmann \& Hinz, 2005 , p. 55) within fifteen years of retirement (Ehnsson, 2008; Schwarz, 2006) given the benefit replacement rate of 60 percent (Grech, 2013). This argument violates the assumption of constant intergenerational transfers: younger generations must shoulder considerably higher tax burdens to receive the same replacement rates. Thus, net benefits decline under the traditional actuarial approach. Consequently, demographic trends broadly offset pension reform effects in the long run (Grech, 2012).

Pension reforms advocates suggest a paradigm shift to replace the principle of solidarity with the principle of strict equivalence (Gill, Packard, \& Yermo, 2005). Retirement benefits depend on structural heterogeneity and rigid labour-market segmentations, reproducing disparities in salary and benefit levels (International Labour Organization, 2001; Perry et al., 2007). Furthermore, contributions create distortions in the labour market, increase the cost of labour, reduce the country's competitiveness, and stimulate the substitution of labour by capital, hence potentially generating higher unemployment. Oppositions to the claims suggest that in the long run the employer contributions are transferred to the workers (through a lower salary) which do not result in a negative impact on employment, although that effect may occur in the short run (International Labour Organization, 2000). 
Based on the premise of the closer link between contributions and benefits, private pension systems may reduce labour market distortions arising from the perceived tax character of contributions to public pension schemes (Laursen, 2000). Critics questioned this assumption arguing that the ultimate goal of a pension system is social welfare not labour supply; furthermore, the benefit delivery shift from defined benefits to defined contributions may create undesirable risks that affect social welfare. Besides, the distortions may occur due to the complexity and the interactions of the labour markets that involves welfare policy, payroll taxation, financial social assistance, and a debtfinanced transition to individual accounts (Barr, 2002; Barr \& Diamond, 2006; Orszag \& Stiglitz, 2001).

Despite the fact that pension systems have shown resistance to reform, most countries demonstrated tremendous resistance towards pension reform, hesitating to bear the political cost of such a decision. However, pension reform seems to be irreversibly needed and therefore governments should take reform strategies that will ensure pension systems remain financially sustainable to provide sufficient and adequate universal coverage to the population.

From the literatures reviewed and the studies made, the need for reform is irreversibly identified. At the same time, the uncertainties of implementing reforms and the nature of the reforms to be made is yet uncertain. The subsequent section will look at the nature of structural reforms.

\section{Structural Reforms}

Governments have been designing multi-pillar pension schemes to replace the out-ofdate single-pillar models. Multi-pillar designs show higher flexibility than single-pillar designs and thus are more suitable to address the needs of the targeted population while being robust enough to withstand major macroeconomic shocks arising from economic, demographic and political volatilities (Chlon, Gora, \& Rutkowski, 1999; Holzmann \& Hinz, 2005; Rutkowski, 1998). Furthermore, a multi-pillar system would attain intra- and inter-pillar optimal risk and desired returns based on asset diversification. Empirical findings from Organisation for Economic Co-operation and Development (OECD) countries support the diversification argument (Thompson, 1998). Moreover, exposing public pension funds to political and regulatory risks turned employees to seek 'safety net' alternatives in private sector institutions (Chlon et al., 1999; Gora \& Rutkowski, 1998).

In essence, structural welfare reforms have turned into a universal panacea for many countries in the last two decades. Welfare reform also involves changes in ownership: privatisation has become the cornerstone of economic-oriented welfare policies, adopting dynamic asset allocation strategies with the highest projected average return (Demirguc-Kunt \& Levine, 1996; Levine \& Zervos, 1998). Linciano (2000) defined privatisation as the transition of traditional pay-as-you-go systems to mandatory or voluntary funded programs. It could take several forms: individual accounts financed by a portion of payroll taxes; government investment of the surplus in private markets; and personal accounts in addition to the payroll tax (Frederick \& Stanley, 2003). 
Diverting funds to private accounts would reduce available funds to pay current retiree benefits. This shift involves transition costs because the state must continue to pay pension to retired beneficiaries and acquired right benefits to employees. Current employees also have partial or full contributions into individual defined-contribution accounts. This dilates the looming predicament rather than solving it. Over time, though, analysts argue that privatisation will progressively metamorphose the social security landscape with the transition from an unfunded pay-as-you-go system to a fully-funded pension, individually capitalised system.

Although the World Bank's three-pillar pension scheme sets the benchmark for pension reform, only a few countries worldwide would condition to launch a threepillar scheme as in the case of Switzerland, Australia, Argentina, Chile, Uruguay, Bolivia, Hong Kong and Kazakhstan, whereas a limited number of countries seem prone to proceed on the three-pillar scheme reform (World Bank, 2006). However, government bodies failed to consider the adverse side effects this strategy would cause, including high participation rates, tax payment irregularities and distortions in labour market mechanisms.

The adoption of a multi-pillar solution carries complex challenges, including basic macroeconomic and financial prerequisites essential for a multi-pillar reform. This include a fiscally feasible plan to address transition costs. Multi-pillar scheme devolvement may hide financial shortfalls that are sufficient to undermine fiscal stability due to the lack of legislative support and precise refinancing assessment. The challenge to streamline systems and processes, optimise revenue cycles and minimise expenditures first before launching a multi-pillar platform is formidable.

Thus far, most countries have reacted by modifying their existing pension systems. The implementation of structural reforms varies on the basis of type and volume. Schwarz (2006) acknowledged four types of structural pension reforms: (i) parametric reforms, (ii) systemic reforms, (iii) regulatory reforms, and (iv) administrative reforms. We will now review the structural reforms from the four aspects below.

\subsection{Parametric Reforms}

Parametric reforms involve systemic approaches for improvement of the fundamental pay-as-you-go mechanisms in an attempt to optimise the system's efficiency either through prolonging productivity capacity of the elderly workforce or smoothing the fiscal costs of population aging. However, in many cases, such approaches proved counterproductive to pension systems with weakened linkage among contributions and benefits.

Participation rates. The increase in the participation rate implies a proportional increase in the cost of the contributions paid in during the active life of the worker, without this translating into greater benefits. Germany, France, Nicaragua and Romania announced reform proposals for gradually increasing the contribution rate ranges from 1 to 4.5 percent over a period that varies from 1 to 20 years. Lithuania alternatively proceeded to a reduction of the participation rate from 5.5 to 2 percent of gross salary (Federacion International De Administradoras De Fondos De Pensiones (FIAP), 2009). A participation rate increase will have a negative impact on net salaries and net benefits. 
Higher participation rates can lead to idle labour demand, informal sector expansion, or impoverished individual saving behaviour. Instead, the preferred alternative is the implementation of a participation rate that labour market can bear and keep constant over time.

Wages conditioned to contributions. In contrast with contribution rates, a wage increase will have a positive impact for employees. Employees will have to pay accordingly higher contributions while expecting also to receive higher benefits in retirement. There will be a positive redistributive effect in the short run and current retirees will receive higher benefits. However, this strategy is Pareto optimal as long as pension deficit is limited enough to render the structural balance positive. Otherwise, the implementation of this strategy will threaten the pension's financial sustainability.

Accrual rate (the rate of benefit per year of service). The accrual rate is the rate at which future benefits accumulate. It is usually part of the pension benefit formula. The accrual rate amounts to a proportion of the final salary, and for its estimation takes into account individual's pensionable membership and final earnings. The accrual rate varies for each individual depending on dates and type of service. The accrual rate is intrinsically associated with the contribution rate, the retirement age, survival postretirement rate and the revalorised wage rate. The decrease of accrual rate will make employees worse off and receive lower benefits. This implies negative redistribution effect to the younger generation and vulnerable population groups. Many countries adjusted the benefits formula or reduced the benefits plan (Brazil, Belgium, Italy, Netherlands and United Kingdom) (Federacion International De Administradoras De Fondos De Pensiones (FIAP), 2009).

Averaging period for wages. The averaging period for wages is referred to as the entire working history of the individual. The average contributions are aligned with the average benefits. This strategy tends to be progressive and favours high-income employees if the benefit formula is based on the final working years.

Revalorisation of wages. Valorisation refers to the actuarial adjustment of the accumulated contributions to the present value of current pension benefits. The actuarial adjustment should reflect changes in costs and standards of living at time of retirement. The most common practice is to revalue earlier years' pay with the growth of average earnings. Valorisation of past earnings may not seem obvious in pension systems, but its impact on retirement incomes is large. The majority of OECD countries revalue accumulated contributions with respect to wage growth. Belgium, France, Greece and Spain revalue accumulated contributions with respect to price growth. Estonia, Finland and Portugal use a mixture of the two, whereas Turkey uses a mix of price and GDP growth (OECD, 2013).

The revalorisation of the wage growth to the average wage growth will impact the contribution rate, respectively. The contribution growth rate will be equal to the average wage growth rate. Employees have ongoing incentives to contribute from the beginning of their career. Setting the wage revalorisation lower than the benchmark, in theory, could be fiscally beneficial in the short run but may undermine fiscal policy in the long run. It will lead to contribution evasion, which in turn, produces adequate benefits to be higher than they would need to be causing a revenue shortfall. As a 
result, several countries have moved away from earnings valorisation in recent years (D’Addio \& Whitehouse, 2012).

Indexation of pensions. Practices vary, but pension indexation is the proper way to preserve the constant rate of return within and across generations. Pension indexation is twofold: referring to rights and benefits paid out. Public pensions can provide a reasonable insurance of pension benefits against wage or price inflation. In the Netherlands, indexation of pension benefits to either wage or price increases has long been considered a guaranteed right. Germany indexes public pensions according to income development. Denmark indexes pension benefits according to wage development. Finland uses a mixture of the two (Hansen, 2006).

The introduction of an automatic pension adjustment mechanism will offer greater pension sustainability even during periods of recession. Absence of indexation apparatus will result in the deterioration of purchasing power of pensions. Wage indexation growth seems to be an unattainable target for most countries. Besides, critics on pension indexed to wage growth levels argue that retirees do not need to increase consumption during the retirement period due to the benefits provided by the state. Pension indexation is subject to debate for both defined-benefit, definedcontribution systems and non-contributory benefits.

Minimum pension. Minimum testing benefits aim at the poor retiree population who live at subsistence level or have special needs in the form of social assistance and support. The value of benefits is usually limited to the unemployed beneficiaries who satisfy certain criteria considering income from other sources, such as a supplementary income, assets and family resources. In Canada, Ireland New Zealand and Denmark which have flat rate pension schemes; there is almost no bond between pension benefits and contributions. Australia and the United Kingdom have significant means-tested public schemes; the bond between pension benefits and contributions is weak. The United States pension scheme consists of a basic contribution component and an earnings-related component calculated according to a progressive formula; the link between pension benefits and contributions fall in between (Dethier, 2007).

Furthermore, numerous countries adopt minimum income requirements in an attempt to improve the adequacy of retirement incomes. In 2011, Finland launched minimum pension requirements as a supplement to the universal type allowance. Greece and Mexico introduced new means-tested benefits during the 2009-2013 period. In 2013, Portugal introduced mean-tested requirements for eligibility to Income Support Allowance, whereas Spain increased survivor benefits for those without a pension (OECD, 2013).

Retirees cannot receive higher benefits than the contributions paid. In addition, the accumulated pension benefits cannot exceed pension assets, which are measured at their fair value. Future pension benefits generally produce estimates using current rather than projected future cash flow earnings. Decreasing minimum pension will definitely lower the redistribution with low-income pensioners to be worse off. Minimum pension equilibrium is attainable as long as it is able to limit out-of-system transfers and encourage individuals to contribute to the system regardless of their 
financial status. Minimum pension affects both funded and unfunded pension schemes as well as side benefits for those who are not eligible for retirement benefits.

Normal retirement age. Normal retirement age ought to be an endogenous parameter and be adjusted according to life expectancy and productivity capacity. Several countries raised retirement ages by taking into account both projected increases in life expectancy and the uncertainty surrounding the estimates in those countries. There is a wide range in projected effective retirement ages in 2050, from 60 (Serbia, Turkey and Luxemburg) to 65 (Austria, Belgium, Hungary, Czech Republic, Slovenia, Romania, Italy, Greece, Bulgaria, South Korea and Nicaragua), 67 (Iceland, Norway, Germany, Denmark, Spain, Israel, Australia and United States) and 68 (United Kingdom) (Federacion International De Administradoras De Fondos De Pensiones (FIAP), 2009; OECD, 2011).

According to Schwarz (2006), pension systems should use the 15-year retirement threshold. An employee who reaches the normal retirement age is entitled to receive payment of his normal retirement benefit. In the case of early retirement, his retirement benefit is his accrued benefit. The level of the accrual rate in this scenario determines the level of retirement age, ceteris paribus. The higher the accrual rate, the longer the individual has to work. A potential increase of retirement age will adversely affect low-income individuals whose life expectancy is generally lower more than high earners. For numerous different reasons, a certain part of the population will not receive the benefits they have already paid for. In this case, deficit gap will be diminished while the rest of the pensioners will receive their benefits. Equalising retirement ages for men and women will substantially increase the pension level for women.

Changes in the conventional retirement age will improve social security's fiscal position. The retaining ready-to-retire senior population fraction in the workforce will generate gains for defined-benefit systems and non-contributory pensions: employee contribution cash flows will increase - senior employees will continue to pay pension contributions and taxes while they will delay claiming of their benefits - for pension expenditures will decrease. Alternatively, defined-contribution systems and voluntary systems will experience redistribution effects: welfare contribution for temporary employment will increase while unemployment benefits may increase, and pension benefits will increase. It is estimated that an individual loses 30 percent of his productivity capacity between 40 to 65 years of age, on average. The level of physical demanding labour determines the level of retirement age, which varies across economic sectors. If age limits human physical performance, then it also limits the value of the accrual rate implying that there is a ceiling on how much a given economy can afford to pay.

Pensionable years of service required. Age and years of service requirements must be met before someone retires. It is possible for someone who meets the service requirement to retire at an earlier age. Thus, a potential increase of years or service will be against low earners whose career in general is shorter. In principle, the short service contribution behaviour is actuarially adjusted to normal contribution behaviour: early retirees will receive a fair proportion of what members would receive at their normal retirement age. Overall, the variation of benefits among members and across economic sectors is insignificant. Minimum vesting standards should be prescribed 
as a necessary condition for a beneficiary to be eligible for retirement benefits. Late pension entrants will be penalised by late members paying higher contributions to satisfy pension system fully or partially vesting requirements. Otherwise, accrual rate could not be set properly.

Early retirement. Early retirement policy was initiated to reduce unemployment (OECD, 1998). The level of accumulated contributions, as well as member's age upon retirement, determines the level of accrual rate. The accrual rate will be adjusted downward for individuals who want to retire before the attainment of normal retirement age, and upwards when individuals decide to delay their retirement. This is beneficial as long as other exogenous factors remain constant. Otherwise, early retirement will shift financial burden to pension funds (Boeri, Brugiavini, \& Maignan, 2001). The dramatic increase of life expectancy in relation to lower birth rates made early retirement unfavourable.

\subsection{Systemic Reforms}

Systemic reforms are usually referred to as the composition of a new component or the introduction of a new pillar. Systemic reforms concern mainly with the diversification of redistribution asymmetries arising from demographic imbalances and uneven contributions and benefits which usually lead to a funding gap or an unfunded liability. Systemic reforms differ with respect to goals and the context of pension pillars.

Many less developed and developing countries have expanded their single-pillar systems well beyond the basic redistributive functions (Bloom \& McKinnon, 2013). The introduction of a zero pillar aims to operate as a safety net providing basic support for everyone. It is a mandatory, publicly managed, tax-financed program that provides mean assistance to beneficiaries living at the subsistence level (Grosh, Del Ninno, Tesliuc, \& Querghi, 2008). In 2008, Chile launched a zero pillar, a new basic solidarity pension plan that integrated with the existing funded pillar and serves as pension supplement to pensioners in the lowest 60 percent of the income distribution (Rudolph, Rocha, \& Vittas, 2010). This reform is seen as a benchmark (Rofman, Fajnzylber, \& Herrara, 2008).

The majority of developed countries with defined-benefit schemes proceeded to either parametric or systemic reforms. The latter refers to the introduction of notional defined-contribution plans or virtual account systems. Notional defined-contribution (NDC) plans constitute a policy countermeasure against the endogenous distortions in the labour markets caused by the rapid growth of the informal sector. Mimicking payas-you-go pattern, NDCs maintain the contributions-to-benefits ratio fixed while the level of benefits varies with life expectancy (Gora \& Palmer, 2004).

In the mid-1990s, Sweden, Poland, Latvia and Italy launched NDC schemes (ChlonDominczak, Franco, \& Palmer, 2012). The Australian, Dutch and United States pension systems considered hybrid plans without deviating from their traditional schemes (Barr, 2006). In 2009, Norway announced the implementation of a pension plan with NDC features. Egypt enacted an NDC reform in 2010 for implementation envisaged in 2013. Uruguay, China, Lebanon, Belarus as well as many EU countries have been considering NDC reform approach (Holzmann, 2012). 
The development of a second and a third pillar suggests a phased retirement: the gradual transition from full-time employment status to part-time employment status to full retirement in exchange for additional income supplement from the three existing pillars. The mandated second-pillar pension schemes are characterised by definedcontribution plans. Chile introduced a second pillar in 1981. Very few emerging and developing countries introduced a second pillar in their existing systems, which are still in the accumulation phase (Holzmann, 2012). Finally, the voluntary third-pillar pension schemes have been variously designed as individual savings accounts, mutual funds and occupational pensions. High administrative and marketing costs and questionable investment management practices have led some governments (i.e., Australia, Denmark, the Netherlands) to espouse regulatory reforms (G. Brunner, Hinz, \& Rocha, 2008).

Systemic reforms proceeded to financing rearrangements concerning the composition of debt structure, shifting pension liabilities from implicit to explicit debt (Holzmann, Palacios, \& Zviniene, 2004; Werding, 2006). Hence, while debt shifting is fiscally restricted, explicit debt is theoretically unrestricted (Eberl, 2015). The periodic rollover of pension promises from one generation to another constitutes a hidden public debt $^{1}$ (Holzmann, 1998; OECD, 1997). Debt shifting prompts a recognition effect of the implicit debt in the form of securitised debt instruments. When the cost of borrowing exceeds the pay-as-you-go contribution rate, ${ }^{2}$ then debt shifting would effectively increase the overall public debt (Cangiano, Cottarelli, \& Cubeddu, 1998). The success of pension transition epicheirema has been under scepticism in countries, of which, public debt lie beyond their fiscal capacity (Barr, 2000; Eisner, 1998; Sawyer, 2003). Heavily indebted countries may lose the confidence of financial markets (Eberl, 2015).

\subsection{Regulatory Reforms}

Regulatory reforms concern improvements to the quality of governance and regulation. Developments in regulatory framework are rarely related to redistributive aspects. Regulatory amendments ensure welfare benefits to all individuals as well as fair treatment of the financially unsophisticated individuals. Transparency in investment management and effective communication management are imperative directives for the governing bodies to set out a prudential framework for pension funds, which have a fiduciary duty to its members to act in their best interests. Setting a minimum guaranteed return, it may create distortions in investment decisions, reduce the window of opportunity for asset diversification, and hamper the performance of pension funds (Schwarz, 2006).

The regulatory framework for privately managed pension funds should also be in compliance with the prudent person principle and/or analogous quantitative portfolio restrictions. The prudent person principle is targeted on the behaviour of pension fund managers in the context of capital markets. The quantitative approach includes security, cash flow management, and risk management concepts (McLeod, Moody, \& Phillips, 1993).

1 International rating agencies have recently stressed their interest in including the amounts and future trends of implicit pension debt in the criteria for their country credit ratings (Hampton, 2011).

2 The rate of return on pay-as-you-go financing is equal to the growth in the contribution base (Samuelson, 1958). 


\subsection{Administrative Reforms}

Administrative reforms' main objective was to reinvent social security, advocating a series of top-to-down shifts with an emphasis in the way pension administration is organised and managed, producing better performance, and requiring greater transparency and accountability. Its concept was associated with a contracting view of the role of governance moving towards a flexible, less conventional bureaucratic framework introducing performance incentives, private-sector techniques, and marketbased strategies to service delivery and administration. This flat-type structure reduces the number of tiers within the organisation, enhances the bottom-to-top information flow, and increases production efficiency (Schwarz, 2006).

\section{Changes in Welfare Fundamental Assumptions for Pension Systems}

According to Torben et al. (2007), there have been several recommendations on how these challenges can be met. Many scholars believe that the solution lay with fundamental factors since their variation caused those welfare system imbalances in the first place. Torben et al. believes that these suggestions turned out to be nonviable in practice.

Economic growth. The raising of the overall GDP rate per se does not solve the problem. Empirically, economic growth is positively correlated with welfare growth as we have seen in most industrial countries during the Golden Age. The concept of perpetual economic growth is implausible. Economic growth cannot resolve the financial dilemma of the welfare state and has deteriorated rather than improve public finances. Economic growth can become a positive indicator for public budget only under the unrealistic assumption that public sector wages and transfers should grow at a slower than the average general income pace.

Higher taxes. One of the underlying motives for taxation lies in funding public pension systems. A moderate tax increase can improve the medium and long-term welfare sustainability from a technical perspective. According to Laffer curve, a hypothetical increase of tax rate beyond a certain point would be counterproductive for raising further tax revenue. This theoretical assumption is realistic for lower taxbracket economies, where the impact from a potential increase of the tax rate will be insignificant; this assumption cannot hold though for higher tax-bracket economies which operate in a dynamic global environment. Higher tax wedges would trigger substitution mechanisms away from work to leisure-type activities and/or encouraging people to look for a job in the informal sector. They can also crowd out private investment, savings and capital accumulation - with an overall negative impact on economic growth.

Higher fertility. The demographic challenges stem from the negative tendencies of longevity and fertility. Population growth may sound an attractive strategy to reverse the negative demographic trends, but actually, it is not. Along with the gradual reductions in labour force participation and employment, changes in population density will have a sizable impact on the old-age dependency ratio. The dramatic increase of young population growth rate implies strong pressures on support and 
education expenditures, and combined with revenue loss, will lead to large deficits in public pension systems. In the absence of other corrective mechanisms, higher fertility rate will not be desirable; in fact, the welfare state will be more vulnerable than previously.

Immigration. In the face of high demand for labour, pensions, health and welfare services, loosening immigration policies could be a possible remedy for many countries. Immigration effects are analysed in economic literature, but the empirical findings are diverse. Relevant studies highlighted the fact that the economic effects of immigration could temporarily cover the unfunded liabilities of the state social programs, but only under certain conditions as follows: 1) The selective admission of young, high-skilled and healthy individuals from the immigration pool, 2) the selective admission among family members of the immigrant that fulfil the above criteria, and 3) immigrants should get less social security benefits (sick leave, unemployment benefits, or early retirement pension benefits) than the native-born population. Even if the unrealistic "immigration without immigrants" conditions could be met, the positive effects of immigration would be offset as immigrants reach retirement age.

\section{A Review of the Shift from a Pay-as-you-go to a Fully-funded System}

Pension reforms have been a subject of debate among economists and policy makers to see whether to shift from the current pay-as-you-go schemes to the fully-funded. Adherents argue that fully-funded pension schemes would better address political and demographic pressures that threaten the financial sustainability of pay-as-you-go pension schemes. Opposition to the ideas have expressed scepticism with respect to the success of pension transition epicheirema if fully funded pension schemes face the same challenges that undermine pay-as-you-go schemes (Barr, 2000; Eisner, 1998; Sawyer, 2003).

A fully-funded social security system has certain advantages: intergeneration transfer risk passes from the government to individuals' accounts; it maintains much of the structure of the current system; government has more opportunities to invest a portion of the funds in equities; national savings will increase, thus inducing future growth in the economy; and, fully-funded system does not change the redistributive structure of the current system. A fully funded system, though has some drawbacks: current consumption will dramatically decrease; and one generation must pay for itself and for the current retirees (Taulbee, 1999).

A significant body of literature acknowledges the possibility of a Pareto-improving transition from an unfunded to a funded system (Breyer, 1989; Breyer \& Straub, 1993; J. K. Brunner, 1994, 1996; Homburg, 1990). The transition from a pay-as-you-go to a fully-funded pension system can be supported by the formation of individual capitalised accounts as a substitutive, parallel, or a mixed system (Mesa-Lago, 2005). A substitutive system is one in which individual accounts replaces the displaced pay-as-you-go pension system. The parallel system indicates the coexistence of both pay-as-you-go and fullyfunded systems. Pension members have the option between the pay-as-you-go and the individual account programs. Finally, a mixed system refers to the complementary character of the embodied individual accounts to the existing pay-as-you-go scheme. 
A transition to a different pension system is not problematic if the economy initially is characterised by either (i) no pension system at all, (ii) a fully-funded system, or (iii) a pay-as-you-go system that is smaller than the pay-as-you-go part of the new system (Matsen \& Thogersen, 2004). It should be noted that this structural change entails transition costs and the whole process may take 40 to 60 years for its completion (World Bank, 2005).

The transition from a pay-as-you-go to a fully funded system is not a Pareto improving transition because it generates an intra-generational redistribution (J.K. Brunner, 1996). System transition creates distortions in the labour market, which cannot be reduced by decreasing the contribution rate (Fenge, 1995). At first, the old system will experience an operating deficit; the system will be left without contributors, but the burden of all current pensions plus those who stayed in the old system. Second, the new pension system should fairly compensate current beneficiaries recognising prior contribution value in full with retroactive and actuarial adjustments, including inflation adjustments and interest paid.

In Chile, the economic downturn coincided with significant pension reforms. Public finances suffered substantial deterioration in the underlying budget deficit with negative implications on real wages and unemployment. Costa Rica preferably adopted a mixed model, adding a second fully-funded compulsory pillar, so the reform did not experience an operating deficit. The case of Argentina was somewhere in between: benefits calculation formula had changed, as the government integrated convertible benefits in order to reimburse middle-aged beneficiaries and stretching the cost out over a longer period (Titelman, Vera, \& Caldentey, 2009).

\section{Is There an Ideal Model?}

Is there any ideal model? According to Lindbeck (2002) the ideal pension model relies on a defined-benefit scheme with defined-contribution elements where the state accepts to manage in a principled manner as well as to financially intervene when needed. Orszag and Stiglitz (2001) have argued that any ideal model is unlikely to be realised in practice. Modigliani and Muralidhar (2004) suggested a two-pillar pension scheme that includes the ideal model mentioned above plus a voluntary definedcontribution scheme. This model is sustainable and viable as long as the compounded contributions along with the expected retirement amount and the expected return of assets is in perfect alignment.

Of course, the contribution rate as well as the replacement rate is unattainable to be estimated, so state intervention is mandatory to eliminate potential system imbalances. It is a pay-as-you-go type scheme, but not based on the inter-generation transfers; individuals contribute to their own individual accounts. The contribution risk is now transferred to the individual per se, as in the case of East Asian provident funds, but without accompanying supplementary funding is abound with shortcomings. The scheme should be partial or fully-funded through variable rate contributions; a fixed amount that will guarantee a minimum pension, plus a voluntary contribution that will guarantee a rate of return. In addition, the state should create a defined-benefit annuity 
based on accumulated balances in individual accounts that will guarantee the real value of return with the use of a swap between the social security agency and the treasury and should be tightened with market returns.

This sinking fund for any surplus receipts the government uses will fully fund the scheme, whereas in the case the actual returns fall short of the guaranteed swap rate, the government will provide additional funds to cover the shortfall. As in the case of provident funds, individuals should be permitted to personal financing, such as education, housing down payments and medical care. In contrast with East Asian provident fund policies, they will use the retirement savings accounts as collateral, subject to strict limitation terms, borrowing at the guaranteed rate.

\section{Concluding Remarks}

The 'one size fits all' pension system does not exist. Each system involves important trade-offs to meet current objectives. Many countries limit reform policies to moderate improvements of their existing social security systems. A few countries proceeded to structural reforms with partial and/or full transition of their existing systems. Reform decisions should be based on a clear understanding of what outcomes the current design influences and how it allocates costs and risks. Governments should seek ways of reforming their pension systems in anticipation of financial burdens in the future (Holzmann, 1988). Pension funds can restore their actuarial balance if policy makers undertake funding-oriented reform initiatives. Notwithstanding, the need for system sustainability constitute an opportunity to re-evaluate existing programs and social trends, considering more fundamental changes.

Given the rapidly changing nature of advanced economies, in terms of demographics, patterns of employment and social risks, recasting is also likely to be an ongoing process. Neither outright benefit retrenchment nor labour market deregulation is necessary for an economy to remain competitive in this global era. Rephrasing Pierson (1999), there is not a single 'new policy' of pension reform, but different policies in different configurations. In the context of a permanent austerity, path-dependence arguments are highly relevant for analysing and explaining the controversial impact of reform policies. The current debate on pension reform calls for a holistic, sustainable approach where all parties coordinate their activities and resources in line with the incentive structures of their existing environment.

\section{References}

Ahsan, S.M., Nivollet, B., McDonald, D., Ruggiero, E., Katz, M., Heller, P., . . Farhadian, Z. (1986). Aging and social expenditure in the major industrial countries, 1980-2025 (IMF Occasional Papers, No. 72). Washington, DC: International Monetary Fund. Retrieved from https://www. imf.org/external/pubs/cat/longres.aspx?sk=212.0

Barr, N. (2000). Reforming pensions: Myths, truths, and policy choices (IMF Working Paper No. 139). Washington, DC: International Monetary Fund.

Barr, N. (2002). Reforming pensions: Myths, truths and policy choices. International Social Security Review, 55(2), 3-36. 
Barr, N. (2006). Non-financial defined contribution pensions: Mapping the terrain. In R. Holzmann \& E. Palmer (Eds.), Penson reform: Issues and prospects for non-financial defined contribution (NDC) schemes (pp. 57-70). Washington, DC: World Bank.

Barr, N., \& Diamond, P.A. (2006). The economics of pensions. Oxford Review of Economic Policy, 22(1), 15-39.

Bloom, D.E., \& McKinnon, R. (2013). The design and implementation of public pension systems in developing countries: Issues and options (IZA Policy Paper No. 59). Bonn, Germany: IZA. Retrieved from http://ftp.iza.org/pp59.pdf:

Boeri, T., Brugiavini, A., \& Maignan, C. (2001). Early retirement: Reasons and consequences. In T. Boeri, A. Borsch-Supan, A. Brugiavini, R. Disney, A. Kapteyn, \& F. Peracchi (Eds.), Pensions: More information, less ideology (pp. 29-53). Boston/Dordrecht: Kluwer.

Breyer, F. (1989). On the intergenerational pareto efficiency of pay-as-you-go financed pension systems. Journal of Institutional and Theoretical Economics, 145(4), 643-658.

Breyer, F., \& Straub, M. (1993). Welfare effects of unfunded pension systems when labour supply is endogenous. Journal of Public Economics, 50(1), 77-91.

Brooks, M.S. (2009). Social protection and the market in Latin America: The transformation of social security institutions. Cambridge, United Kingdom: Cambridge University Press.

Brunner, G., Hinz, R., \& Rocha, R. (2008). Risk-based supervision of pension funds: Emerging practices and challenges. Washington, DC: World Bank.

Brunner, J.K. (1994). Redistribution and the efficiency of the pay-as-you-go pension system. Journal of Instituional and Theoretical Economics, 150(3), 511-523.

Brunner, J.K. (1996). Transition from a pay-as-you-go to a fully funded pension system: The case of differing individuals and intragenerational fairness. Journal of Public Economics, 60(1), 131146.

Cangiano, M., Cottarelli, C., \& Cubeddu, L. (1998). Pension developments and reforms in transition economies (IMF Working Paper No. WP/98/151). Washington, DC: International Monetary Fund. Retrieved from https://www.imf.org/external/pubs/ft/wp/wp98151.pdf

Chlon, A., Gora, M., \& Rutkowski, M. (1999). Shaping pension reform in Poland: Security through diversity (Social Protection Discussion Paper 9928). Washington, DC: World Bank.

Chlon-Dominczak, A., Franco, D., \& Palmer, E. (2012). The first wave of NDC reforms: The experiences of Italy, Latvia, Poland and Sweden. In R. Holzmann, E. Palmer, \& D. Robalino (Eds.), Nonfinancial defined contribution pension schemes in a changing pension world (Vol. 1: Progress, lessons and implementation). Washington, DC: World Bank.

D'Addio, A.C., \& Whitehouse, E. (2012). Towards financial sustainability of pension systems: The role of automatic-adjustment mechanisms in OECD and EU countries. Paris: Organisation for Economic Co-operation and Development. Retrieved from https://www.researchgate.net/ publication/232701219

Davis, E.P. (1995). Pension funds, retirement-income security and capital markets: An international perspective. Oxford: Oxford University Press.

Demirguc-Kunt, A., \& Levine, R. (1996). Stock market development and the financial intermediaries: Stylized facts. World Bank Economic Review, 10(2), 291-321.

Dethier, J.-J. (2007). Social security: What can developing countries learn from developed countries? Paper presented at the Taking Action for the World Poor and Hungry People Conference, Beijing.

Disney, R. (2000). Crises in public pension programmes in OECD: What are the reform options? The Economic Journal, 110(461), F1-F23.

Eberl, J. (2015). The political economy of public debt and social security: Repayment in times of fiscal distress. Paper presented at the 52nd Annual Conference of the Public Choice Society, San Antonio, Texas. 
Ehnsson, G. (2008). Old-age pension systems in the Nordic countries. Copenhagen: Nordic Social-Statistical Committee. Retrieved from https://norden.diva-portal.org/smash/get/ diva2:968720/FULLTEXT01.pdf

Eisner, R. (1998). Save social security from its saviours. Journal of Post Keynsesian Economics, 21(1), 77-92.

Federacion International De Administradoras De Fondos De Pensiones (FIAP). (2009). The impact on workers of the parametric changes in the PAYGO programs. Santiago, Chile: Author. Retrieved from http://www.apapr.ro/images/BIBLIOTECA/crizaglobala/fiap\%20crisis\%20 payg\%202009.pdf

Fenge, R. (1995). Pareto-efficiency of the pay-as-you-go pension system with intragenerational fairness. FinanzArchiv / Public Finance Analysis, 52(3), 357-363.

Fox, L., \& Palmer, E. (2001). New approaches to multipillar pension systems: What in the world is going on? Paper presented at The Year 2000 International Research Conference on Social Security, Helsinki. Retrieved from https://www.researchgate.net/profile/Louise_Fox2/ publication/40967857_New_Approaches_to_Multipillar_Pension_Systems_What_in_the_ World_Is_Going_On/links/0c96052bdad7475968000000.pdf

Frederick, S.M., \& Stanley, G.E. (2003). Financial markets and institutions (4th ed.). Boston, MA: Addison Wesley Publishers.

Gill, S.I., Packard, T., \& Yermo, J. (2005). Keeping the promise of social security in Latin America. Palo Alto, CA: Stanford University Press and Washington, D.C.: World Bank.

Gora, M., \& Palmer, E. (2004). Shifting perspectives in pension reform (IZA Discussion Paper No. 1369). Bonn, Germany: Institute of Labour Economics (IZA).

Gora, M., \& Rutkowski, M. (1998). The quest for pension reform: Poland's security through diversity (Social Protection Discussion Paper No. SP 9815). Washington, DC: World Bank.

Grech, G.A. (2012). Evaluating the possible impact of pension reforms on future living standards in Europe (CASEpapers No. 161). London, UK: Centre for Analysis of Social Exclusion, London School of Economics. Retrieved from http://eprints.Ise.ac.uk/51296/1/_Libfile_repository_ Content_Grech\%2C\%20AG_Grech_Evaluating_possible_\%20impact_2012_Grech_Evaluating_ possible_\%20impact_2012_author.pdf

Grech, G.A. (2013). How best to measure pension adequacy (CASEpapers No. 172). London, UK: Centre for Analysis of Social Exclusion, London School of Economics. Retrieved from http:// eprints.Ise.ac.uk/51270/1/_Libfile_repository_Content_Grech,\%20AG_Grech_How_best_ measure_2013.pdf

Grosh, M., Del Ninno, C., Tesliuc, E., \& Querghi, A. (2008). For protection \& promotion: The design and implementation of effective safety nets. Washington, DC: World Bank.

Hampton, T. (2011). Combining debt and pension liabilities of U.S. States enhances comparability. Retrieved from http://www.nasra.org/resources/Moodys1101.pdf

Hansen, H. (2006). Public pension schemes in seven European countries: A micro-simulation approach. Hauppauge, New York: Nova Science Publications Inc.

Hauner, D., Leigh, D., \& Skaarup, M. (2007). Ensuring fiscal sustainability in G-7 countries (IMF Working Paper, No. 07/187). Washington, DC: International Monetary Fund. https://www. imf.org/external/pubs/cat/longres.aspx?sk=21100.0

Holzmann, R. (1988). Reforming public pensions. Paris: OECD.

Holzmann, R. (1998). Financing the transition to multipillar (Social Protection Discussion Paper Series, No. 9809). Washington, DC: World Bank. Retrieved from http://documents. worldbank.org/curated/en/571471468173341364/pdf/200520REVISED0Box385311 B00PUBLIC009809.pdf

Holzmann, R. (2012). Global pension systems and their reform: Worldwide drivers, trends, and challenges (IZA Discussion Paper No. 6800). Bonn, Germany: Institute of Labour Economics (IZA). Retrieved from http://ftp.iza.org/dp6800.pdf 
Holzmann, R., \& Hinz, R. (2005). Old-age income support in the 21st century: An interntional perspective on pension systems reform. Washington, DC: World Bank. Retrieved from http:// www.apapr.ro/images/BIBLIOTECA/reformageneralitati/bm\%20income\%20support\%202005. pdf

Holzmann, R., Palacios, R., \& Zviniene, A. (2004). Implicit pension debt: Issues, measurement and scope in international perspective (Social Protection Discussion Paper Series, No. 0403). Washington, DC: World Bank. Retrieved from http://siteresources.worldbank.org/ SOCIALPROTECTION/Resources/SP-Discussion-papers/Pensions-DP/0403.pdf

Homburg, S. (1990). The efficiency of unfunded pension schemes. Journal of Institutional and Theoretical Economics, 146(4), 640-647.

Hur, M.H. (2010). A comparative study of the relationship between pension plans and individual savings in Asian countries from an institutional point of view. International Journal of Social Welfare, 19(4), 379-389.

International Labour Organization. (2000). World labour report 2000: Income security and social protection in a changing world. Geneva, Switzerland: Author. Retrieved from http://www.ilo. org/public/english/standards/relm/gb/docs/gb279/pdf/esp-7.pdf

International Labour Organization. (2001). Social security: A new consensus (Report prepared for the 89th International Labour Conference), Geneva, Switzerland: Author.

Kane, C., \& Palacios, R. (1996). The implicit pension debt. Finance and Development, 33(2), 36-38.

Lakonishok, J., Shleifer, A., \& Vishny, R.W. (1992). The structure and performance of the money management industry. Brooking Papers on Economic Activity: Microeconomics, 339-379.

Laursen, T. (2000). Pension system viability and reform alternatives in the Czech Republic (IMF Working Paper No. WP/00/16). Washington, DC: International Monetary Fund. Retrieved from https://www.imf.org/external/pubs/ft/wp/2000/wp0016.pdf

Levine, R., \& Zervos, A. (1998). Stock markets, banks, and economic growth. American Economic Review, 88(3), 537-558.

Linciano, N. (2000). Privatization of social security: Theoretical issues and empirical evidence from four countries' reforms. Quaderni Di Finanza, 40(August), 1-49.

Lindbeck, A. (2002). The European social model: Lessons for developing countries (ERD Working Paper Series No. 11). Manila, Philippines: Asian Development Bank. Retrieved from https:// www.adb.org/sites/default/files/publication/28180/wp011.pdf

Matsen, E., \& Thogersen, O. (2004). Designing social security - A portfolio choice approach. European Economic Review, 48(4), 883-904.

McLeod, W.R., Moody, S., \& Phillips, A. (1993). The risks of pension plans. Financial Services Review, 2(2), 131-156.

Mesa-Lago, C. (2005). Pension reforms: Results and challenges. Journal of Pension Economics and Finance, 4(2), 218-219.

Modigliani, F., \& Muralidhar, A. (2004). Rethinking pension reform. Cambridge, United Kingdom: Cambridge University Press.

Muller, K. (2001). The making of pension privatization: Latin America and East European cases. Paper presented at the Political Economy of Pension Reform, Laxenburg, Austria.

Newbery, D., \& Stern, N. (1987). The theory of taxation for developing countries. Oxford: Oxford University Press.

OECD. (1997). Fiscal alternatives of moving from unfunded to funded pensions (Working Paper AWP 5.2) Paris: Author. Retrieved from http://www.oecd.org/els/public-pensions/2429222. pdf

OECD. (1998). Maintaining prosperity in an ageing society. Paris: Author. http://dx.doi.org/ 10.1787/9789264163133-en

OECD. (2000). Reforms for an ageing society. Paris: Author. http://dx.doi.org/10.1787/ 9789264188198-en 
OECD. (2011). Pensions at a glance 2011: Retirement-income systems in OECD and G20 countries. Paris: Author. http://dx.doi.org/10.1787/pension_glance-2011-en

OECD. (2013). Pensions at a glance 2013: OECD and G20 indicators. Paris: Author. http://dx.doi. org/10.1787/pension_glance-2013-en

Orszag, P., \& Stiglitz, J. (2001). Rethinking social security: Ten myths about social security systems. In R. Holzman \& J. Stiglitz (Eds.), New Ideas About Old Age Security (pp. 17-56). Washington, D.C.: World Bank.

Perry, G.E., Maloney, W.F., Arias, O.S., Fanjnzylber, P., Mason, A.D., \& Saavedra-Chanduvi, J. (2007). Informality: Exit and exclusion. Washington, D.C.: International Bank for Reconstruction and Development / World Bank.

Pierson, P. (1999). Coping with permanent austerity: The politics of welfare state restructuring in affluent democracies. In P. Pierson (Ed.), The New Politics of the Welfare State (pp. 410-456). New York, NY: Oxford University Press.

Ponds, E., Severinson, C., \& Yermo, J. (2011). Funding in public sector pension plans: International evidence (NBER Working Paper 17082). Retrieved from http://www.nber.org/papers/w17082. pdf

Radian, A. (1980). Resource mobilization in poor countries. London: Transcaction Books.

Rofman, R., Fajnzylber, E., \& Herrara, G. (2008). Reforming the pension reforms: The recent initiatives and actions on pensions in Argentina and Chile (SP Discussion Paper, No. 0831). Washington, DC: World Bank. Retrieved from http://siteresources.worldbank.org/ SOCIALPROTECTION/Resources/SP-Discussion-papers/Pensions-DP/0831.pdf

Rudolph, H.P., Rocha, R., \& Vittas, D. (2010). The payout phase of pension systems: A comparison of five countries (World Bank Policy Research Working Papers No. 5288). Washington, DC: World Bank. Retrieved from http://elibrary.worldbank.org/doi/abs/10.1596/1813-9450-5288

Rutkowski, M. (1998). A New Generation of Pension Reforms Conquers the East: A Taxonomy in Transition Economies. Transition, 9(4), 16-19.

Samuelson, P.A. (1958). An exact consumption-loan model of interest with or without the social contrivance of money. Journal of Political Economy 66(6), 467-482.

Sawyer, M. (2003). An economic evaluation of alternative arrangements for retirement pensions. Paper presented at the conference on Privatization of Public Pension Systems: Forces, Experiences, Prospects, Vienna, Austria.

Schneider, O. (2009). Reforming pensions in Europe: Economic fundamentals and political factors (IES Working Paper 8/2009). Prague, Czech Republic: Institute of Economic Studies, Faculty of Social Sciences, Charles University. Retrieved from http://ies.fsv.cuni.cz/default/file/ download/id/10182

Schwarz, A.M. (2006). Pension System Reforms. Washington, DC: World Bank.

Schwarz, A.M., \& Demirguc-Kunt, A. (1999). Taking stock of pension reforms around the world (Social Protection Discussion Paper Series, No. 9917). Washington, DC: World Bank.

Taulbee, N. (1999). The benefits of a fully funded social security system. The Park Place Economist, VII, 76-82. Retrieved from http://www.iwu.edu/economics/PPE07/

Thompson, L.H. (1998). Older and wiser: The economics of public pensions. Washington, DC: The Urban Institute Press.

Titelman, D., Vera, C., \& Caldentey, P.E. (2009). Pension system reform in Latin America and potential implications for the Chinese case (IDEAs Working Paper Series, No. 06/2009). New Delhi, India: International Development Economics Associates.

Torben, M.A., Holmstrom, B., Honkapohja, S., Korkman, S., Soderstrom, H.T., \& Vartiainen, J. (2007). The Nordic model: Embracing globalization and sharing risks. Helsinki: The Research Institute of the Finnish Economy (ETLA).

Van Der Nood, P., \& Herd, R. (1994). Estimating pension liabilities - A methodological framework. OECD Economic Studies, 23(Winter), 131-166. 
Vittas, D. (1993). Swiss Chilanpore: The way forward for pension reform? (World Bank Policy Research Working Papers Series, No 1093). Retrieved from http://documents.worldbank.org/ curated/en/659261468740411744/pdf/multi-page.pdf

Weber, A. (2010). Financing social health insurance: Challenges and opportunities. In S.W. Handayani (Ed.), Enhancing social protection in Asia and the Pacific: The proceedings of the regional workshop (pp. 249-265). Mandaluyong City, Philippines: Asian Development Bank.

Werding, M. (2006). Implicit pension debt and the role of public pensions for human capital accumulation: An assessment for Germany. Munich, Germany: IFO Institute for Economic Research \& CESifo. Retrieved from http://hermes-ir.lib.hit-u.ac.jp/rs/bitstream/10086/ 14172/1/pie_dp283.pdf

World Bank. (1994). Averting the old age crisis: Policies to protect the old and promote growth. New York, NY: Oxford University Press for the World Bank. Retrieved from http://documents. worldbank.org/curated/en/973571468174557899/pdf/multi-page.pdf

World Bank. (2005). Transition: Paying for a shift from pay-as-you-go finanching to funded pensions (World Bank Pension Reform Primer Series). Washington, DC: Author. Retrieved from https://openknowledge.worldbank.org/handle/10986/11242

World Bank. (2006). Pension reform and the development of pension systems: An evaluation of World Bank assistance. Washington, DC: Author. 
